\title{
Effect of embryo cryopreservation techniques on reproductive and growth traits in rabbits
}

\author{
Josep Cifre ${ }^{\mathrm{a}}$, Manuel Baselga ${ }^{\mathrm{a} *}$, Ernesto Angel Gómez ${ }^{\mathrm{b}}$, \\ García M. de la Luz \\ a Departamento de Ciencia Animal, Universidad Politécnica de Valencia, \\ Camino de Vera 14, Apdo 22012, 46071 Valencia, Spain \\ b Unitat de Cunicultura (IRTA), Torre Marimón, Caldes de Montbui, 08140 Barcelona, Spain
}

(Received 20 January 1998; accepted 8 June 1998)

\begin{abstract}
The combined effects of embryo recovery, embryo cryopreservation and embryo transfer techniques on growth and reproductive characters of rabbits were studied. The animals coming from cryopreserved embryos were penalized for individual average daily gain during the fattening period in $1.72 \mathrm{~g} / \mathrm{d}(P<0.05)$ when they were compared to animals born after natural matings and pregnancies. The difference disappeared when we analysed the same character in the progeny. The litter size class effects were linear for weaning and slaughter weight and non-linear for daily gain, pointing out the independence of this character with respect to maternal effects. There were no differences for litter size or kindling interval between the animals. Growth characters were affected by the season effects ( 706.8 versus $654.3 \mathrm{~g}$ in weaning weight and 1940.6 versus $1875.1 \mathrm{~g}$ in slaughter weight; spring versus summer, $P<0.05$ ). Also, the reproductive characters had the lower value for litter size in summer and the higher kindling interval ( 52.3 versus 45.4 days; summer versus spring, $P<0.05$ ). It is concluded that the experiments using cryopreserved animals should work with the progeny of those animals instead of with themselves, especially for growth characters, in order to avoid the possible negative effects observed. (O) Elsevier/Inra
\end{abstract}

embryo / cryopreservation / reproduction / growth / rabbit

Résumé - Effets des techniques de cryoconservation d'embryons sur les caractères de croissance et de reproduction du lapin. Les effets des techniques de collecte, de cryoconservation et de transfert d'embryons sur les caractères de croissance et de reproduction du lapin on été étudiés. Comparés à des animaux conçus et nés de façon naturelle, les animaux issus d'embryons cryoconservés sont pénalisés sur le gain moyen quotidien de $1,72 \mathrm{~g} \cdot \mathrm{j}^{-1}(p<0,05)$ pendant l'engraissement. Cette différence disparaît lorsqu'elle est analysée sur les descendants des animaux issus d'embryons cryoconservés. Les effets de la classe des tailles de portée étaient linéaires pour les poids au sevrage et à

* Correspondence and reprints

Tel.: (34) 9638774 30; fax: (34) 963877439. 
l'abattage ; ils étaient non linéaires pour le gain moyen quotidien, mettant en évidence l'indépendance de ce caractère par rapport aux effets maternels. Il n'y avait pas de différences entre les animaux pour la taille de la portée ou l'intervalle entre les mises bas. Les caractères de croissance étaient affectés par les effets de la saison (706,8 versus 654,3 g pour le poids au sevrage et 1940,6 versus 1875,1 g pour le poids à l'abattage; printemps versus été, $p<0,05$ ). La taille de la portée était la plus faible en été et l'intervalle entre mises bas était le plus élevé en été $(52,3$ versus $45,4 \mathrm{j}$; été versus printemps, $p<0,05$ ). Il est conclu que les expériences utilisant des animaux issus d'embryons cryoconservés doivent être réalisées sur les descendants de ces animaux et non sur ces animaux eux-mêmes, tout spécialement pour les caractères de croissance, afin d'éviter les éventuels effets négatifs observés dans cette étude. (1) Elsevier / Inra

embryon / cryopréservation / reproduction / croissance / lapin

\section{INTRODUCTION}

The development of cell and molecular biology together with new reproductive techniques are becoming quite common in animal production [26]. Today, the application of molecular genetics is very limited in rabbit production [15]. However, reproductive techniques such as artificial insemination and embryo cryopreservation are well developed in rabbits $[17,24]$. There are different methods of embryo cryopreservation with similar results at birth, but with different technical efforts, vitrification being the easiest method at present [13].

The main applications of embryo cryopreservation are the conservation of genetic resources [12, 19], the establishment of control populations in the experiments of estimation of genetic responses to selection [19] or to avoid health, time and housing problems in several experiments such as the foundation of new lines [4]. However, there are no experiments in the literature related with the effects of these techniques on the characters of interest in rabbit production, but these effects are important in experiments that assess genetic response. The objective of this paper is to evaluate the effects of embryo recovery, cryopreservation and transferring techniques on growth and reproductive characters of rabbits.

\section{MATERIALS AND METHODS}

Three groups of rabbits were compared on growth and reproductive characters and on growth characters of their progeny. All the animals came from the fourteenth generation of line $\mathrm{V}$, a maternal rabbit line selected on a number of young weaned at the experimental farm of the Universidad Politécnica de Valencia [5]. The control group consisted of rabbits born and raised by their dams after a natural mating and pregnancy. The other two groups came from deliveries of females that became pregnant by transferring pooled frozen or vitrified embryos. A description of embryo recovery, cryopreservation and transferring techniques used are described by Vicente and García-Ximénez [22, 23, 25]. The does of the control group were mated on Fridays, delivered mainly on Tuesday and the weaning was always on Tuesday. Thus the age at weaning for this group was highly concentrated around 28 days. In the other two groups, the induction of the ovulation of the recipient does was on Wednesday, the transfer on Fridays and the majority of does delivered on Sundays. The weaning was also on Tuesday and consequently, in these groups the more frequent age at weaning was 30 days.

Rabbits were born and kept at the experimental farm of the UPV until the end of their fattening period. Then the females were moved to a commercial farm $30 \mathrm{~km}$ far from the University to control their reproductive performance and the growth characters of the progeny. Animals were fed ad libitum during the fattening period with a commercial pelleted feed $(16 \%$ crude protein, $15.5 \%$ crude fibre and $3.4 \%$ ether extract). The females were managed under natural mating twice a week (Monday and Friday) with 
a rebreeding interval of 12 days. The parities took place mainly on Thursday and Monday and the weanings on Wednesday. So the modes of age at weaning were 27 or 30 days, respectively. The females were also fed ad libitum with a commercial pelleted feed ( $17.5 \%$ crude protein, $14.5 \%$ crude fibre and $3.4 \%$ ether extract).

Growth characters were individual weaning weight (at 28 days of age, in grams), individual weight at the end of the fattening period (at 63 days of age, in grams) and individual average daily gain during the fattening period (in grams per day) and were analysed both in the three groups of animals and in their offspring. Growth characters were analysed with the following mixed linear model:

$$
y_{i j k l m}=m+T_{i}+S_{j}+L_{k}+d_{1}+e_{i j k l m}
$$

where $y_{i j k l m}$ is the trait to analyse; $m$ is the general mean; $T_{i}$ is the fixed effect of type of animal (control, frozen or vitrified); $S_{i}$ is the fixed effect of season in which the animal was born (spring or summer); $L_{k}$ is the fixed effect of litter size in which the animal was born $(<5,6,7, \ldots$, $>13$ number born alive); $d_{1}$ random effect of the doe supporting the pregnancy and the lactation (it has been assumed that the doe effects were noncorrelated); and $\mathrm{e}_{\mathrm{ijklm}}$, is the residual.

Growth characters of the progeny were analysed with the following mixed linear model :

$$
\begin{aligned}
y_{i j k l m n o p}= & m+T_{i}+R E_{j}+Y_{k}+L_{1}+A W_{m} \\
& +d_{n}+I_{o}+e_{i j k l m n o p}
\end{aligned}
$$

where $y_{i j k l m n o p}$ is the trait to analyse; $m$ is the general mean; $T_{i}$ is the fixed effect of type of the doe (control, frozen or vitrified); $\mathrm{RE}_{\mathrm{j}}$ is the fixed effect of reproductive state of the doe (nulliparous and primiparous or multiparous lactating and non lactating doe at conception); $\mathrm{YS}_{\mathrm{k}}$ is the fixed effect of year-season of birth; $L S_{1}$ is the fixed effect of litter size in which an animal was born $\left(<4,5,6, \ldots,>11\right.$ number born alive); $\mathrm{AW}_{\mathrm{m}}$ is the fixed effect of age at weaning (27 or 30 days); $d_{n}$, random effect of the doe (it has been assumed that the doe effects were uncorrelated); $l_{0}$ is the random effect of the litter in which an animal was born; and $\mathrm{e}_{\mathrm{ijklmnop}}$ is the residual.

The reproductive characters studied were number of total born, number of born alive, number weaned, number at the end of the fattening period and kindling interval. They were analysed with the following mixed lineal model:

$$
\begin{aligned}
y_{i j k l m n o}=m+T_{i} & +T_{j}+R E_{k}+Y_{1}+d_{m}+I_{n} \\
& +e_{i j k l m n o}
\end{aligned}
$$

where $y_{i j k l m n o}$ is the trait to analyse; $m$ is the general mean; $T_{j}$ is the fixed effect of type of animal (control, frozen or vitrified); $\mathrm{TP}_{\mathrm{j}}$ is the fixed effect of type of parity (Monday or Thursday); $\mathrm{RE}_{\mathrm{k}}$ is the fixed effect of reproductive state of the doe (nulliparous and primiparous or multiparous lactating and non lactating doe at conception); $\mathrm{YS}_{1}$ is the fixed effect of year-season of birth; $d_{m}$ random effect of the doe (it has been assumed that the doe effects were uncorrelated); $l_{n}$ is the random effect of the litter in which the doe was born; and $\mathrm{e}_{\mathrm{ijk} k \mathrm{mnno}}$ is the residual.

The statistical methods used were restricted maximum likelihood [20] to estimate variance components, using a derivative free algorithm [10] software package (VCE) [11]. Fixed effects and their contrasts were obtained by generalized least squares [18], using the variance components estimated.

\section{RESULTS AND DISCUSSION}

\subsection{Growth characters}

Number of data and a brief summary statistics of growth characters are given in table I. Table II shows the variance com-

Table I. Number of records (N), maximum (Max), minimum (Min), average (AVG) and standard deviation (STD) for growth characters.

\begin{tabular}{lrrrrr}
\hline Character $^{1}$ & N & Max & Min & AVG & STD \\
\hline WW $(\mathrm{g})$ & 410 & 1100 & 280 & 618.2 & 130.7 \\
SW $(\mathrm{g})$ & 410 & 2470 & 1000 & 1853.8 & 203.0 \\
DG $(\mathrm{g} / \mathrm{d})$ & 410 & 47.7 & 12.3 & 35.3 & 3.5 \\
\hline
\end{tabular}

\footnotetext{
${ }^{1}$ Weaning weight in $g(W W)$, slaughter weight in $g$ (SW) and average daily gain in g per day (DG).
} 
Table II. Doe $\left(\sigma^{2}{ }_{\mathrm{d}}\right)$ and error $\left(\sigma_{\mathrm{e}}^{2}\right)$ variance components and doe intraclass correlation with its standard error $\left(\rho_{d} \pm\right.$ S.E. $)$ for growth characters.

\begin{tabular}{lrrr}
\hline Character $^{1}$ & $\sigma_{\mathrm{d}}^{2}$ & $\sigma_{\mathrm{e}}^{2}$ & $\rho_{\mathrm{d}} \pm$ S.E. \\
\hline WW (g) & 3354 & 7586 & $0.31 \pm 0.075$ \\
SW (g) & 6711 & 27646 & $0.19 \pm 0.057$ \\
DG (g/d) & 2.63 & 10.34 & $0.20 \pm 0.055$
\end{tabular}

' Weaning weight in $\mathrm{g}(\mathrm{WW})$, slaughter weight in $\mathrm{g}$ (SW) and average daily gain in $\mathrm{g}$ per day (DG).

ponents of doe and error effects estimated by REML. The doe intraclass correlations and their standard errors are also reported. We must note the higher intraclass correlation for weaning weight, agreeing with the well known fact that this trait has more important maternal effects [6] than postweaning daily gain and slaughter weight. The season effects are shown in table III. They confirm the depressing effect of temperature on the weight of animals $[3,8,21]$. Table $I V$ reports on the litter size class effects. The linearity of these effects for weaning and slaughter weight is remarkable, the similarity of them for these two traits and the irrelevance and non-linearity of litter size class effects for daily gain. This result, again, is indicative of the independence of daily gain with respect to maternal effects.

There were no significant differences between animals coming from frozen or vit-

Table III. Generalized least square means and standard errors for season effects in growth characters.

\begin{tabular}{lccc}
\hline Character $^{1}$ & WW $(\mathrm{g})$ & SW $(\mathrm{g})$ & DG $(\mathrm{g} / \mathrm{d})$ \\
\hline Spring & $706.8 \pm 14.3^{\mathrm{b}}$ & $1940.6 \pm 24.0^{\mathrm{b}}$ & $35.2 \pm 0.5$ \\
Summer & $654.3 \pm 10.6^{\mathrm{a}}$ & $\mathbf{1 8 7 5 . 1} \pm 17.1^{\mathrm{a}}$ & $34.8 \pm 0.3$ \\
\hline
\end{tabular}

' Weaning weight in $\mathrm{g}(\mathrm{WW})$, slaughter weight in $\mathrm{g}(\mathrm{SW})$ and average daily gain in $\mathrm{g}$ per day (DG). a.b Values with different superscripts are significantly different $(P<0.05)$.

Table IV. Generalized least square means, standard errors and regression coefficient (b) of litter size class effect on litter size classes for growth characters.

\begin{tabular}{lccc}
\hline LSC $^{2}$ & \multicolumn{3}{c}{ Character $^{1}$} \\
\cline { 2 - 4 } & WW $(\mathrm{g})$ & $\mathrm{SW}(\mathrm{g})$ & $\mathrm{DG}(\mathrm{g} / \mathrm{d})$ \\
\hline$<5$ born alive & $897.5 \pm 29.0^{\mathrm{d}}$ & $2125.3 \pm 51.5^{\mathrm{e}}$ & $35.12 \pm 1.00^{\mathrm{abc}}$ \\
5 & $866.8 \pm 27.1^{\mathrm{d}}$ & $2117.3 \pm 46.8^{\mathrm{e}}$ & $35.70 \pm 0.91^{\mathrm{abc}}$ \\
6 & $818.9 \pm 41.6^{\mathrm{d}}$ & $2044.7 \pm 66.6^{\mathrm{de}}$ & $35.01 \pm 1.30^{\mathrm{abc}}$ \\
7 & $691.8 \pm 25.4^{\mathrm{c}}$ & $1911.3 \pm 43.0^{\mathrm{bcd}}$ & $34.83 \pm 0.84^{\mathrm{abc}}$ \\
8 & $689.8 \pm 22.6^{\mathrm{c}}$ & $1966.3 \pm 37.2^{\mathrm{cd}}$ & $36.64 \pm 0.73^{\mathrm{c}}$ \\
9 & $631.0 \pm 26.4^{\mathrm{bc}}$ & $1822.7 \pm 43.1^{\mathrm{ab}}$ & $33.94 \pm 0.84^{\mathrm{a}}$ \\
10 & $650.2 \pm 21.0^{\mathrm{c}}$ & $1887.8 \pm 34.3^{\mathrm{bc}}$ & $35.40 \pm 0.67^{\mathrm{ab}}$ \\
11 & $572.2 \pm 20.1^{\mathrm{ab}}$ & $1795.1 \pm 33.1^{\mathrm{a}}$ & $34.75 \pm 0.65^{\mathrm{ac}}$ \\
12 & $560.8 \pm 23.7^{\mathrm{a}}$ & $1737.2 \pm 39.6^{\mathrm{a}}$ & $33.53 \pm 0.77^{\mathrm{a}}$ \\
$>13$ & $533.2 \pm 35.1^{\mathrm{a}}$ & $1734.5 \pm 57.0^{\mathrm{a}}$ & $34.28 \pm 1.11^{\mathrm{abc}}$ \\
\hline $\mathrm{b}$ & $573.7 \pm 25.5^{\mathrm{ab}}$ & $1844.2 \pm 42.8^{\mathrm{ab}}$ & $36.26 \pm 0.84^{\mathrm{bc}}$ \\
\hline
\end{tabular}

\footnotetext{
' Weaning weight in $\mathrm{g}$ (WW), slaughter weight in $\mathrm{g}$ (SW) and average daily gain in g per day (DG).

${ }^{2}$ Litter size classes in number born alive.

a. b.c, d, e Values with different superscripts are significantly different $(P<0.05)$.
} 
rified embryos on any character studied (table $V$ ). However, the contrasts between these two groups and the control group show that animals coming from cryopreserved embryos have a higher weaning weight $(70.3 \mathrm{~g})$ and a reduced growth during the fattening period $(1.72 \mathrm{~g} / \mathrm{d})$. The differences in weaning weight can be completely explained by the age of rabbits at weaning. The young of the control group were weaned at an average age of 28 days, the other two at 30 days. The individual average daily gain at this age is around $34-37 \mathrm{~g} / \mathrm{d}$ [7] and consequently the expected difference is $70 \mathrm{~g}$. Very important is the difference in individual average daily gain during the fattening period $(1.72 \mathrm{~g} / \mathrm{d})$. This result means that when comparing naturally reproduced animals with animals coming from frozen or vitrified embryos it will be necessary to add a correction factor $(1.72 \mathrm{~g} / \mathrm{d})$ to the daily gain data of the latter. An alternative could be to compare not directly animals of the groups but their progeny, if the absence of effects in those animals is confirmed. This approach will have some advantages as to diminish the number of frozen or vitrified embryos required in some experiments but has the inconvenience of taking more time.

\subsection{Growth characters of the progeny}

Growth characters of the offspring were measured in a commercial farm on more than 1000 young rabbits (table VI) in order to check if the differences observed in the parents disappear in their progeny. The variance components for random effects in the model are shown in table VII. It is remarkable the fact that doe and litter effects take account of 40 to $50 \%$ of the total variance of growth characters. For daily gain, litter effects are more important than it was expected, probably due to the fact that the experiment was done on a commercial farm. When these characters are studied in an experimental farm, as in the analysis of growth characters or in Estany et al. [6], maternal and litter effects are less important in determining daily gain. The results concerning the fixed effects are presented

Table V. Generalized least square means and standard errors for vitrified, frozen and control group effects on growth characters.

\begin{tabular}{lccc}
\hline Character' $^{\prime}$ & WW $(\mathrm{g})$ & SW $(\mathrm{g})$ & DG $(\mathrm{g} / \mathrm{d})$ \\
\hline Vitrified & $699.6 \pm 17.1^{\mathrm{b}}$ & $1911.4 \pm 28.1$ & $34.78 \pm 0.55^{\mathrm{a}}$ \\
Frozen & $708.4 \pm 17.9^{\mathrm{h}}$ & $1913.7 \pm 29.7$ & $34.16 \pm 0.58^{\mathrm{a}}$ \\
Control & $633.7 \pm 11.8^{\mathrm{a}}$ & $1898.4 \pm 19.6$ & $36.19 \pm 0.38^{\mathrm{b}}$ \\
\hline
\end{tabular}

${ }^{1}$ Weaning weight in $\mathrm{g}$ (WW), slaughter weight in $\mathrm{g}$ (SW) and average daily gain in g per day (DG).

a. b Values with different superscripts are significantly different $(P<0.05)$.

Table VI. Number of records (N), maximum (Max, minimum (Min, average (AVG) and standard deviation (STD) for growth characters of the offspring.

\begin{tabular}{lcrrrr}
\hline Character' $^{\prime}$ & $\mathrm{N}$ & Max & Min & AVG & \multicolumn{1}{c}{ STD } \\
\hline WW $(\mathrm{g})$ & 2072 & 1070 & 160 & 571.7 & 163.2 \\
SW $(\mathrm{g})$ & 1454 & 2500 & 1000 & 1806.8 & 267.2 \\
DG $(\mathrm{g} / \mathrm{d})$ & 1449 & 51.10 & 15.4 & 34.6 & 5.2 \\
\hline
\end{tabular}

I Weaning weight in $\mathrm{g}(\mathrm{WW})$, slaughter weight in $\mathrm{g}$ (SW) and average daily gain in ger day (DG). 
Table VII. Doe $\left(\sigma_{\mathrm{d}}^{2}\right)$, litter in which an animal has born $\left(\sigma_{c}^{2}\right)$ and error $\left(\sigma_{\mathrm{e}}^{2}\right)$ variance components for growth characters of the offspring.

\begin{tabular}{lrrr}
\hline Character $^{1}$ & $\sigma^{2}{ }_{\mathrm{d}}$ & \multicolumn{1}{c}{$\sigma^{2}{ }_{\mathrm{c}}$} & \multicolumn{1}{c}{$\sigma_{{ }_{\mathrm{c}}}$} \\
\hline WW (g) & 1982 & 5715 & 7153 \\
SW (g) & 7170 & 22283 & 29532 \\
DG (g/d) & 2.13 & 9.70 & 13.08
\end{tabular}

I Weaning weight in $\mathrm{g}$ (WW), slaughter weight in $\mathrm{g}$ (SW) and average daily gain in g per day (DG).

in table VIII. Year-season effects do not show a clear pattern but hot seasons like summer and autumn seem to penalize growth characters, as pointed before. The results concerning the physiological state of the doe at mating do not show any clear result, probably due to the fact that the number of data for non-lactating does was very small. On the contrary, litter size class seems to affect weaning weight and weight at the end of the fattening period. Individual average daily gain, as in the preceding experiment, seems not to be affected by this effect. The age at weaning was also significant for weaning weight and weight at the end of the fattening period, but not for daily gain.

The main result concerns the effect of cryopreservation on growth characters of the progeny (table IX). It can be seen how the differences in individual average daily gain during the fattening period that emerged when comparing control group and cryopreserved groups do not appear when analysing the same character on the off-

Table VIII. Generalized least square means and standard errors for year-season of birth (YS), physiological state of the doe (FS), litter size (LS) and age at weaning (AW) effects on growth characters of the offspring.

\begin{tabular}{llccc}
\hline Character $^{1}$ & & WW & SW & DG \\
\hline YS & Autumn 93 & $574.5 \pm 22.9^{\mathrm{ab}}$ & $1776.0 \pm 48.1$ & $33.9 \pm 0.97^{\mathrm{a}}$ \\
& Winter 94 & $582.5 \pm 146^{\mathrm{ab}}$ & $1848.2 \pm 32.5$ & $35.7 \pm 0.66^{\mathrm{b}}$ \\
& Spring 94 & $597.8 \pm 16.5^{\mathrm{b}}$ & $1796.3 \pm 36.0$ & $34.1 \pm 0.73^{\mathrm{ab}}$ \\
& Summer 94 & $532.2 \pm 26.5^{\mathrm{a}}$ & - & - \\
FS & & & & \\
& Nulliparous & $543.1 \pm 16.6^{\mathrm{a}}$ & $1828.9 \pm 31.8$ & $36.3 \pm 0.65^{\mathrm{b}}$ \\
& Prim. lact. & $604.1 \pm 17.4^{\mathrm{b}}$ & $1846.9 \pm 36.2$ & $34.9 \pm 0.74^{\mathrm{ab}}$ \\
& Prim. non lact. & $561.4 \pm 29.7^{\mathrm{ab}}$ & $1798.0 \pm 61.1$ & $34.7 \pm 1.24^{\mathrm{ab}}$ \\
& Mult. lact. & $595.2 \pm 14.4^{\mathrm{b}}$ & $1795.4 \pm 36.6$ & $33.6 \pm 0.74^{\mathrm{a}}$ \\
& Mult. non lact. & $555.0 \pm 28.6^{\mathrm{ab}}$ & $1764.8 \pm 69.8$ & $33.4 \pm 1.43^{\mathrm{ab}}$ \\
LS & & & & \\
& $1-3$ born alive & $817.3 \pm 50.6^{\mathrm{d}}$ & $2071.9 \pm 143.5^{\mathrm{f}}$ & $32.9 \pm 2.95$ \\
& $4-5$ & $711.2 \pm 26.0^{\mathrm{d}}$ & $2011.4 \pm 59.6^{\mathrm{ef}}$ & $36.2 \pm 1.22$ \\
& 6 & $584.8 \pm 24.1^{\mathrm{c}}$ & $1842.3 \pm 53.6^{\mathrm{df}}$ & $35.9 \pm 1.10$ \\
& 7 & $574.6 \pm 24.4^{\mathrm{c}}$ & $1759.5 \pm 53.7^{\mathrm{cd}}$ & $33.6 \pm 1.10$ \\
& 8 & $593.3 \pm 19.7^{\mathrm{c}}$ & $1816.6 \pm 39.8^{\mathrm{df}}$ & $35.0 \pm 0.81$ \\
& 9 & $495.1 \pm 16.4^{\mathrm{b}}$ & $1752.1 \pm 34.4^{\mathrm{bcd}}$ & $35.3 \pm 0.70$ \\
& 10 & $502.8 \pm 16.2^{\mathrm{b}}$ & $1706.29 \pm 34.9^{\mathrm{abc}}$ & $34.1 \pm 0.71$ \\
& 11 & $437.8 \pm 16.5^{\mathrm{a}}$ & $1655.0 \pm 34.8^{\mathrm{ac}}$ & $34.2 \pm 0.71$ \\
& $>11$ & $428.7 \pm 18.3^{\mathrm{a}}$ & $1646.2 \pm 39.0^{\mathrm{ac}}$ & $34.1 \pm 0.79$ \\
AW & & & & \\
& 27 days & $489.2 \pm 14.9^{\mathrm{a}}$ & $1728.0 \pm 35.5^{\mathrm{a}}$ & $34.8 \pm 0.71$ \\
& 30 days & $654.3 \pm 14.1^{\mathrm{b}}$ & $1885.6 \pm 29.9^{\mathrm{b}}$ & $34.3 \pm 0.60$
\end{tabular}

\footnotetext{
1 Weaning weight in $\mathrm{g}(\mathrm{WW})$, slaughter weight in $\mathrm{g}$ (SW) and average daily gain in $\mathrm{g}$ per day (DG).
}

u. h,c,d.c.f Values with different superscripts are significantly different $(P<0.05)$. 
Table IX. Generalized least square means and standard errors for vitrified, frozen and control group effects on growth characters of the offspring.

\begin{tabular}{lccc}
\hline Character $^{l}$ & WW & SW & DG \\
\hline Vitrified & $559.6 \pm 17.6^{\mathrm{a}}$ & $1815.9 \pm 37.5$ & $35.2 \pm 0.74$ \\
Frozen & $601.7 \pm 17.8^{\mathrm{b}}$ & $1814.9 \pm 39.3$ & $33.9 \pm 0.78$ \\
Control & $553.9 \pm 14.3^{\mathrm{a}}$ & $1789.6 \pm 32.5$ & $34.7 \pm 0.65$ \\
\hline
\end{tabular}

' Weaning weight in $\mathrm{g}(\mathrm{WW})$, slaughter weight in $\mathrm{g}(\mathrm{SW})$ and average daily gain in $\mathrm{g}$ per day (DG).

a.h Values with different superseripts are significantly different $(P<0.05)$.

Table X. Number of records (N), maximum (Max), minimum (Min), average (AVG) and standard deviation (STD) for reproductive characters.

\begin{tabular}{lccccc}
\hline Character $^{1}$ & $\mathrm{~N}$ & Max & Min & AVG & STD \\
\hline TB & 309 & 17 & 1 & 9.1 & 2.8 \\
BA & 309 & 16 & 0 & 8.4 & 3.3 \\
NW & 303 & 12 & 0 & 7.1 & 3.2 \\
NS & 193 & 12 & 0 & 6.1 & 3.5 \\
KI & 219 & 98 & 35 & 46.5 & 10.9
\end{tabular}

' Number of born (TB), number of born alive (BA), number of weaned (NW), number at the end of the fattening period (NS) and kindling interval (KI, in days).

spring. The same can be said for the weight at the end of the fattening period. However, the results for weaning weight show how the animals coming from frozen parents have higher weaning weight than animals from vitrified or control parents. This result was not expected and there can be given no explanation for it. The animals coming from cryopreserved parents have more similarities between them than with the offspring of the control group, because their parents have been recovered, cryopreserved and transferred at embryo stages. This implies that the differences between the progeny of the three groups are expected to appear between the control and the other two groups, but not in the way they have been found. It should also be said that the importance of the difference found is quite low (around $45 \mathrm{~g}$, less than $10 \%$ of the values for the character).

\subsection{Reproductive characters}

Reproductive characters of cryopreserved and control animals were analysed in a commercial farm during 4 seasons. The values for litter size are lower than the ones obtained for line $\mathrm{V}$ in other experiments [2, 21 ], probably due to the lower technical level of the commercial farm when compared with the experimental farm (table $X$ ). Variance components of random effects of the model are presented in table XI. The zero values of doe and litter components for kindling interval are remarkable, implying zero values of repeatability. Similar results have been obtained by Baselga et al. [1] when analysing characters related with kindling interval. For litter size traits, the repeatabilities are around $0.12-0.17$, in accordance with the values found in the literature [14]. However, phenotypic variances 
Table XI. Doe $\left(\sigma^{2}{ }_{d}\right)$, litter in which an animal was born $\left(\sigma_{\mathrm{c}}^{2}\right)$ and error $\left(\sigma_{\mathrm{e}}^{2}\right)$ variance components for reproductive characters.

\begin{tabular}{lrrr}
\hline Character $^{1}$ & $\sigma_{\mathrm{d}}^{2}$ & \multicolumn{1}{c}{$\sigma^{2}{ }_{\mathrm{c}}$} & \multicolumn{1}{c}{$\sigma^{2}{ }_{\mathrm{c}}$} \\
\hline TB & 0.906 & 0 & 6.407 \\
$\mathrm{BA}$ & 1.387 & 0 & 9.285 \\
$\mathrm{NW}$ & 1.644 & 0.612 & 8.152 \\
$\mathrm{NS}$ & 0.768 & 0.846 & 9.824 \\
KI & 0 & 0 & 112.964
\end{tabular}

${ }^{1}$ Number of born (TB). number of born alive (BA), number of weaned (NW), number at the end of the fattening period (NS) and kindling interval (KI, in days).

are higher than the ones obtained by Gómez [9] in the same line but in the UPV experimental farm.

Year-season and reproductive state of the doe effects are presented in table XII. With respect to year-season the lower values for litter size in summer, and the higher kindling interval in that season are remarkable. The values for autumn are also lower than the ones for winter and spring, probably due to the fact that the animals are still affected by the higher temperatures suffered during summer. The least square means for the physiological state of the doe do not show statistical differences in any character studied.

There are no statistical differences for litter size or kindling interval between the three groups of animals studied (table XIII). However, some differences are quite important between the groups, with values around 0.8 pups between control and vitrified groups for litter size. The non-stable management conditions during the experiment in the commercial farm could be the reason for the higher phenotypic variances in the characters and of the high standard errors obtained. Despite this, it should be noted that the differences between vitrified and frozen animals are superior than the ones between frozen and control group, which is in accordance with the random nature of the differences between groups. Also, it is remarkable that the differences in litter size between the groups are the consequence of the differences observed in total born, as they do not change when litter size is measured at different ages of pups.

Table XII. Generalized least square means and standard errors for year-season (YS) and physiological state of the doe (FS) effects on reproductive characters.

\begin{tabular}{|c|c|c|c|c|c|c|}
\hline \multicolumn{2}{|c|}{ Character ${ }^{I}$} & \multirow{2}{*}{$\frac{\mathrm{TB}}{8.7 \pm 0.6^{\mathrm{ab}}}$} & \multirow{2}{*}{$\frac{\text { BA }}{8.1 \pm 0.7^{\mathrm{ab}}}$} & \multirow{2}{*}{$\frac{\mathrm{NW}}{7.2 \pm 0.7^{\mathrm{h}}}$} & \multirow{2}{*}{$\frac{\text { NS }}{5.5 \pm 0.9^{\mathrm{h}}}$} & \multirow{2}{*}{$\frac{\mathrm{KI}}{-}$} \\
\hline YS & Autumn 93 & & & & & \\
\hline & Winter 94 & $8.8 \pm 0.3^{\mathrm{ab}}$ & $8.4 \pm 0.4^{\mathrm{b}}$ & $7.2 \pm 0.4^{\mathrm{b}}$ & $6.2 \pm 0.6^{\mathrm{h}}$ & $39.9 \pm 2.6^{a}$ \\
\hline & Spring 94 & $9.6 \pm 0.4^{b}$ & $9.1 \pm 0.5^{b}$ & $7.2 \pm 0.5^{\mathrm{b}}$ & $5.7 \pm 0.8^{b}$ & $45.4 \pm 1.8^{\mathrm{b}}$ \\
\hline & Summer 94 & $7.8 \pm 0.6^{\mathrm{a}}$ & $6.7 \pm 0.7^{\mathrm{a}}$ & $5.0 \pm 0.7^{a}$ & $1.1 \pm 1.4^{\mathrm{a}}$ & $52.3 \pm 2.1^{\mathrm{c}}$ \\
\hline \multirow[t]{5}{*}{$\mathrm{FS}^{2}$} & Nulliparous & $8.6 \pm 0.4$ & $7.7 \pm 0.5$ & $6.5 \pm 0.5$ & $4.8 \pm 0.8$ & $52.4 \pm 2.1^{\mathrm{c}}$ \\
\hline & Prim. lact. & $8.8 \pm 0.4$ & $7.7 \pm 0.5$ & $6.1 \pm 0.5$ & $4.8 \pm 0.8$ & $49.6 \pm 1.7^{\mathrm{hc}}$ \\
\hline & P. non lact. & $9.2 \pm 0.8$ & $8.9 \pm 1.0$ & $7.4 \pm 0.9$ & $5.1 \pm 1.4$ & $46.0 \pm 1.9^{\mathrm{ab}}$ \\
\hline & Mult. lact. & $9.1 \pm 0.4$ & $8.2 \pm 0.4$ & $6.7 \pm 0.4$ & $5.2 \pm 0.7$ & $43.2 \pm 2.2^{\mathrm{a}}$ \\
\hline & M. non lact. & $8.1 \pm 0.7$ & $7.8 \pm 0.8$ & $6.6 \pm 0.8$ & $3.3 \pm 1.3$ & $44.2 \pm 3.3^{3 \mathrm{abc}}$ \\
\hline
\end{tabular}

${ }^{1}$ Number of born (TB), number of born alive (BA), number of weaned (NW), number at the end of the fattening period (NS) and kindling interval (Kl, in days).

${ }^{2}$ For kindling interval, this effect has five levels: interval between first and second parity, between second and third, etc. i. h.c Values with different superseripts are significantly different $(P<0.05)$. 
Table XIII. Generalized least square means and standard errors for vitrified, frozen and control group effects on reproductive characters.

\begin{tabular}{lccccc}
\hline Character $^{l}$ & TB & BA & NW & NS & KI \\
\hline Vitrified & $8.3 \pm 0.4$ & $7.6 \pm 0.5$ & $6.2 \pm 0.6$ & $4.2 \pm 0.7$ & $46.2 \pm 1.9$ \\
Frozen & $8.9 \pm 0.4$ & $8.1 \pm 0.5$ & $6.7 \pm 0.5$ & $4.8 \pm 0.7$ & $47.0 \pm 1.9$ \\
Control & $9.1 \pm 0.3$ & $8.4 \pm 0.4$ & $7.1 \pm 0.4$ & $4.9 \pm 0.6$ & $44.3 \pm 1.4$ \\
\hline
\end{tabular}

${ }^{1}$ Number of born (TB), number of born alive (BA), number of weaned (NW), number at the end of the fattening period (NS) and kindling interval (KI, in days).

\section{CONCLUSIONS}

The results obtained concerning the effects of recovery, cryopreservation and transferring techniques on growth and reproductive characters of rabbits and on growth characters of their progeny suggest that it should be recommended to work with the offspring of the animals cryopreserved in order to avoid the use of correction factors, specially with growth characters. Season effects affect growth characters, litter size and kindling interval, the worst values being in summer. The linearity of litter size class effects for weaning and slaughter weights is significant. However, some results obtained in the commercial farm should be taken with care because they seem to be influenced by the unstable conditions in that farm.

\section{ACKNOWLEDGEMENTS}

The authors thank all the farmers of the UPV experimental farm and also V. Navarro and family for housing facilities and the care put with the animals. This work has been supported by an FPI grant AP92-43014161 from the Spanish Ministry of Education and Culture, and it is included in the Spanish Research Project AGF940577.

\section{REFERENCES}

[1] Baselga M., Blasco A., Garcia F., Parámetros genéticos de caracteres económicos en poblaciones de conejos, in: 2 nd. World Congress on Genetics Applied to Livestock Production, Madrid, Spain, vol. 6, 1982, pp. 471-480.
[2] Baselga M., Gómez E.A., Cifre J., Camacho J., Genetic diversity of litter size traits between parities in rabbits, J. Appl. Rabbit Res. 15 (1992) 198-205.

[3] Castellini C., Panella F., Heritability of pre- and postweaning weights in rabbits, in: 4th World Rabbit Congress, Budapest, vol. 2, 1988, 112-119.

[4] Cifre J., Baselga M., García-Ximénez F., Vicente J.S., Performance of a rabbit line founded selecting on hyperprolificacy I. Litter size traits, J. Anim. Breed. Genet. (1998), in press.

[5] Estany J., Baselga M., Blasco A., Camacho J., Mixed model methodology for the estimation of genetic response to selection in litter size of rabbits, Livest. Prod. Sci. 21 (1989) 67-75.

[6] Estany J., Camacho J., Baselga M., Blasco A., Selection response of growth rate in rabbits for meat production, Genet. Sel. Evol. 24 (1992) 527-537.

[7] Feki S., Études comparatives des caractéristiques de croissance et de l'efficience alimentaire chez trois lignées de lapins, thesis Master of Science, IAMZ, Zaragoza, Spain, 1994.

[8] Feki S., Baselga M., Blas E., Cervera C., Gómez E.A., Comparison of growth and feed efficiency among rabbit lines selected for different objectives, Livest. Prod. Sci. 45 (1996) 87-92.

[9] Gómez E.A., La selección del tamaño de camada en el conejo de carne: influencia de los efectos maternos y de la heterogeneidad genética entre partos, Doctoral thesis, Universidad Politécnica de Valencia, Spain, 1994.

[10] Graser H.W., Smith C., Tier B., A derivativefree approach for estimating variance components in animal models by Restricted Maximum Likelihood, J. Anim. Sci. 64 (1987) 1362-1370.

[11] Groeneveld E., VCE A multivariate multimodel REML (co)variance component estimation package, 5th World Congress on Genetics Applied to Livestock Production, Guelph, vol. 22, 1994, pp. 47-48.

[12] Joly T., Théau-Clément M., Drouet-Viard F., de Rochambeau H., Renerd J.P., Application de la cryoconservation des embryons à la protection des ressources génétiques chez le lapin, Génét. Sel. Evol. 26 (1994) 267s-278s. 
[13] Kasai H., Hamaguchi Y., Zhu S.E., Miyake T., Sakurai T., Machida T., High survival of rabbit morulae after vitrification in an ethylene glycol-based solution by a simpled method, J. Reprod. Fertil. 89 (1992) 91-97.

[14] Khalil M.H., Diversity of repeatability between parities for litter traits and reproductive intervals in doe rabbits, World Rabbit Sci. I (1993) 147-154.

[15] Mulsant P., Rochambeau H. de, Possible contribution of molecular genetics to the rabbit future, 6th World Rabbit Congress 2 (1996) 229-234.

[16] Patterson H.D., Thompson R., Recovery of interblock information when block sizes are unequal, Biometrika 58 (1971) 545-554.

[17] Renard J.P., Garnier V., Parvex R., Production et congelation de l'embryon de lapin, $3^{c}$ Journées de la Recherche Cunicole, Communication $18,1982$.

[18] Searle S.R., Linear models, John Wiley and Sons, New York, 1971.

119] Smith C., Genetic aspects of conservation in farm livestock. Livest Prod. Sci. 11 (1984) $37-48$.

[20] Smith C.,Checking rates of genetic response with new reproductive techniques, $3^{\circ}$ Congrès Mondial de Reproduction et Sélection des Ovins et Bovins à Viande Y, 1988, pp. 159-171.
[21] Torres C., Baselga M., Gómez E.A., Effect of weight daily gain selection on gross feed efficiency in rabbits, J. Appl. Rabbit Res. 15 (1992) 884-888.

122] Vicente J.S., García-Ximénez. F.. Effect of strain and embryo transfer model (embryos from one versus two donor does/recipient) on results of cryopreservation in rabbit, Reprod. Nutr. Dev. 33 (1993) 5-13.

[23] Vicente J.S., García-Ximénez F., Effect of recipjent doe genotype on survival rate at birth of frozen rabbit embryos, Reprod. Nutr. Dev. 33 (1993) 229-234.

124] Vicente J.S., García-Ximénez F., Control hormonal de la reproducción, Conservación de gametos y embriones. VI Jornada Técnica sobre Cunicultura, 24-41, Expo aviga'93, Barcelona. 1993.

[25] Vicente J.S., García-Ximénez F., Osmotic and cryoprotective effects of a mixture of DMSO and ethylene glycol on rabbit morulae, Theriogenology 42 (1994) 1205-1215.

[26] Wilmut Y., Reproduction technologies, 5th World Congress on Genetics Applied to Livestock Production 20, 1994, p. 171. 